\title{
Alkaline treatments to render starch-based biodegradable polymers self-mineralizable
}

\author{
I. B. Leonor ${ }^{1,2,3 *}$, H.-M. Kim ${ }^{4}$, F. Balas ${ }^{3}$, M. Kawashita ${ }^{5}$, R. L. Reis ${ }^{1,2}$, T. Kokubo ${ }^{3}$ and T. Nakamura ${ }^{6}$ \\ ${ }^{1}$ 3Bs Research Group, Department of Polymer Engineering, University of Minho, Campus de Gualtar, 4710-057 Braga, Portugal \\ ${ }^{2}$ IBB - Institute for Biotechnology and Bioengineering, PT Government Associated Laboratory, Braga, Portugal \\ ${ }^{3}$ Department of Biomedical Sciences, College of Life and Health Sciences, Chubu University, 1200 Matsumoto Kasugai, Aichi 487-8501 \\ Japan \\ ${ }^{4}$ Department of Ceramic Engineering, School of Advanced Materials Engineering, Yonsei University, 134 Shinchon-dong, \\ Seodaemun-gu, Seoul 120-749, Korea \\ ${ }^{5}$ Ion Beam Engineering Experimental Laboratory, Graduate School of Engineering, Kyoto University, Nishikyo-ku, Kyoto 615-8510, \\ Japan \\ ${ }^{6}$ Department of Orthopaedic Surgery, Faculty of Medicine, Kyoto University, Sakyo-ku, Kyoto 606-8506, Japan
}

\begin{abstract}
The present research aims to develop a new route for surface functionalization of biodegradable polymers. The method is based on a wet chemistry modification, resulting in etching and/or hydrolysis in order to increase the amount of polar groups, such as hydroxyl $(-\mathrm{OH})$ and carboxylic $(-\mathrm{COOH})$ groups on the surface of the polymer. The polymer used as substrate was a corn starch-ethylene vinyl alcohol biodegradable blend (SEVA-C). For that purpose it was used in two different types of activation: (a) calcium hydroxide solution $\left[\mathrm{Ca}(\mathrm{OH})_{2}\right]$ and (b) sodium hydroxide solution $(\mathrm{NaOH})$. These treatments lead to the formation carboxylic acid-rich SEVA-C surfaces. Then, the samples were soaked in simulated body fluid (SBF) for different time periods of time until 7 days. After 1 day in SBF, the surface of SEVA-C was fully covered with spherulite particles. As the soaking time increased, the particles increased and coalesced, leading to the formation of a dense and uniform layer. Furthermore, thin-film X-ray diffraction confirms that the layer formed on the surface of the polymer was an apatite-like layer. These results suggest that this rather simple treatment is a good method for surface functionalization and subsequent mineral nucleation and growth on biodegradable polymeric surfaces to be used for bone-related applications. Copyright $\odot$ 2008 John Wiley \& Sons, Ltd.
\end{abstract}

Received 27 September 2007; Accepted 4 November 2007

Keywords apatite; simulated body fluid (SBF); bioactivity; biodegradable polymer; functional groups; starch-based polymers

\section{Introduction}

In the last century, there has been substantial growth in the research leading to the development of new biodegradable polymers to be used in the medical field. Devices obtained with biodegradable polymers present great advantages over the metal implants, and are the best alternative for the temporary internal fixation of

\footnotetext{
"Correspondence to: I. B. Leonor, 3Bs Research Group, Department of Polymer Engineering, University of Minho, Campus de Gualtar, 4710-057 Braga, Portugal. E-mail: belinha@dep.uminho.pt
}

many different kinds of tissue damage over the metal implants. Also, they have the capacity to transfer stress over time to the damaged area, allowing healing of the tissues, and eliminate the need for a subsequent operation for implant removal, which is of substantial benefit both economically and to the human being involved (Bostman et al., 2000; Hastings et al., 1994; Hayashi et al., 1994; Middleton et al., 2000; Rokkanen et al., 1991; Vainionpää et al., 1989).

Such materials that degrade slowly and predictably in the human body are useful in several medical applications, especially those serving temporary functions, such as sutures, bone fixation devices, applications related to 
reconstructive surgery, scaffolding for cells that recreate damaged or diseased organs and controlled-release drug delivery devices. On the other hand, it has not yet been possible to develop new types of materials, having not only osteoconductivity but also mechanical properties analogous to those of natural bone, and also with suitable degradation behaviour. Furthermore, one aspect that is very important for biodegradable materials is their biocompatibility; this means that the material must degrade without eliciting an inflammatory response or an extreme immunogenicity or cytotoxicity (Suh et al., 1998; Temenoff et al., 2000).

In the last 12 years, starch-based polymers have been proposed (Boesel et al., 2004a, 2004b; Elvira et al., 2002; Gomes et al., 2002, 2003, 2006; Malafaya et al., 2006; Mano et al., 2003, 2004; Marques et al., 2002; Mendes et al., 2001, 2003; Reis et al., 1995, Reis et al., 1996, 1997, 2000; Salgado et al., 2004, 2005; Sousa et al., 2000, 2002; Vaz et al., 2001) as alternative biomaterials for temporary biomedical applications. One of the main advantages of these materials for uses in bonerelated applications is the combination of the mechanical performance with a degradable behaviour (Azevedo et al., 2003, Mano et al., 2000, 2004; Reis et al., 1996, 1997; Sousa et al., 2002; Vaz et al., 2001). Additionally, it has been shown (Gomes et al., 2001; Marques et al., 2002, 2003, 2005a, 2005b; Mendes et al., 2001, 2003; Reis et al., 1996, 2000; Salgado et al., 2004, 2005) that these materials can comply with the biocompatibility requirements of a biomaterial, as defined in international standards, which is not typical of biodegradable systems. Also, compared to other biodegradable polymers present in the market, starch-based blends are the cheapest and are available in much larger quantities from several renewable plants sources. For instance, one major merit of starch-based polymers is the ability to control their surface properties in such a way that a favourable interaction of the surface-modified material and the biological system is achieved (Demirgoz et al., 2000).

It has been shown that blends of starch with ethylene-vinyl alcohol co-polymer, designated SEVA-C, can associate a degradable behaviour with an interesting mechanical performance (Azevedo et al., 2003; Mano et al., 2000, 2004; Oliveira et al., 2004; Reis et al., 1996, 1997; Sousa et al., 2002; Vaz et al., 2001). However, in terms of bone bonding, this polymer cannot induce by itself the formation of an apatite layer without a previous bioactive coating or the use of bioactive fillers, as has been reported previously (Leonor et al., 2002a, 2002b, 2003, 2004; Leonor et al., 2003, Oliveira et al., 1999, 2003, 2005; Pashkuleva et al., 2005).

Biological responses such as bone-bonding ability of the materials are very important in bone-related applications. More specifically, a biologically active bone-like apatite layer has been shown (Kim et al., 2001, 2003; Kokubo et al., 2003, 2004, 2006) to be a prerequisite to bonding of artificial material to living bone.

In nature, organisms control mineralization through the use of macromolecules (Campbell et al., 1999).
It is well known that these macromolecules contain functional groups which are negatively charged at the crystallization $\mathrm{pH}$ and promote the apatite nucleation (Campbell et al., 1999; Weiner et al., 1986). The study of inorganic-organic interfaces is therefore an important aspect of biomimetic materials chemistry, which seeks to develop new synthetic routes to functional materials that are organized on various length scales from the nano-scale to macroscopic.

Tanahashi et al. (1997) demonstrated that when a surface that is negatively charged is soaked in SBF, it acts as an effective substrate for the apatite nucleation. They found that the incorporation of $-\mathrm{H}_{2} \mathrm{PO}_{4}$ and $-\mathrm{COOH}$ groups on self-assembled monolayers is effective for the apatite nucleation. On the other hand, functional groups such as $-\mathrm{CONH}_{2},-\mathrm{OH},-\mathrm{NH}_{2}$ and $-\mathrm{CH}_{3}$ had weaker apatite nucleating ability (Tanahashi et al., 1997). Among these functional groups, the incorporation of $-\mathrm{SO}_{3} \mathrm{H}$ groups onto polymeric surfaces could also serve as the functional active group for calcium phosphate nucleation (Leonor et al., 2005, 2007).

The key point lies in the design of an organized functionalized surface to control the mechanisms of the heterogeneous nucleation. One of the advantages of using polymeric systems is the capacity to tailor their surface properties in order to achieve different properties, such as making the surfaces more hydrophilic and capable of carrying functional groups. An organic and quite hydrophilic material, such as SEVA-C, is a suitable material for inducing apatite nucleation, as in fact biological mineralization is thought to be induced by anionic functional groups. So, the presence of reactive $-\mathrm{OH}$ groups on starch and vinyl alcohol justifies the present efforts in trying to incorporate other polar groups, such as $-\mathrm{COOH}$, to obtain bioactive polymers.

The main aim of this research was to investigate apatite formation on biodegradable polymeric substrates by soaking them in $\mathrm{Ca}(\mathrm{OH})_{2}$ and $\mathrm{NaOH}$ solutions for $24 \mathrm{~h}$ and subsequent immersion in SBF for several time periods up to 7 days. The polymeric substrates were characterized by field-emission scanning electron microscopy (FESEM) with an attached energy dispersive electron probe X-ray analyser (EDS), thin-film X-ray diffraction (TF$\mathrm{XRD}$ ), Fourier transform attenuated total reflectance infrared spectroscopy (FT-IR) and X-ray photoelectron spectroscopy (XPS).

\section{Materials and methods}

\subsection{Substrate}

A biodegradable thermoplastic blend of corn starch with ethylene-vinyl alcohol (50:50 wt \%), designated as SEVA-C, was used as substrate. This polymer was obtained by conventional injection moulding in a KlocknerFerromatik Desma FM20 machine in order to produce circular samples with a diameter of $10 \mathrm{~mm}$ and a thickness of $1.6 \mathrm{~mm}$. Further details on the material processing and 
respective mechanical properties can be found elsewhere (Reis et al., 1995, 1996, 2001). The substrates were abraded with No. 400 diamond paste, ultrasonically washed with distilled water, and dried at $40^{\circ} \mathrm{C}$ for $24 \mathrm{~h}$.

\section{2. $\mathrm{Ca}(\mathrm{OH})_{2}$ and $\mathrm{NaOH}$ treatments}

Two alkaline solutions were used for producing a carboxylic acid-rich SEVA-C surface: (a) $\mathrm{Ca}(\mathrm{OH})_{2}(6.7 \mathrm{~mm})$ saturated solution; and (b) $\mathrm{NaOH}(1.0 \mathrm{~m})$ solution. The polymers were soaked in $50 \mathrm{ml} \mathrm{Ca}(\mathrm{OH})_{2}$ in polystyrene sterile flasks and $5 \mathrm{ml} \mathrm{NaOH}$ solutions in Teflon ${ }^{\circledR}$ tubes for $24 \mathrm{~h}$ at $40^{\circ} \mathrm{C}$ and shaken at 120 strokes/min. After the soaking, the samples were washed extensively with distilled water.

\subsection{Soaking in simulated body fluid (SBF)}

$\mathrm{NaOH}$ and $\mathrm{Ca}(\mathrm{OH})_{2}$-treated substrates were soaked in a simulated body fluid (SBF; Kokubo et al., 1990) with ion concentrations $\left(\mathrm{Na}^{+} 142.0, \mathrm{~K}^{+} 5.0, \mathrm{Ca}^{2+} 2.5, \mathrm{Mg}^{2+}\right.$ 1.5, $\mathrm{Cl}^{-} 147.8, \mathrm{HCO}_{3}{ }^{-} 4.2, \mathrm{HPO}_{4}{ }^{2-} 1.0$, and $\mathrm{SO}_{4}{ }^{2-} 0.5$ $\mathrm{mm}$ ) nearly equal to those of the human blood plasma, at $36.5^{\circ} \mathrm{C}$ for different periods up to 7 days. The SBF was prepared by dissolving reagent-grade chemicals of $\mathrm{NaCl}, \mathrm{NaHCO}_{3}, \mathrm{KCl}, \mathrm{K}_{2} \mathrm{PO}_{4} 3 \mathrm{H}_{2} \mathrm{O}, \mathrm{MgCl}_{2} 6 \mathrm{H}_{2} \mathrm{O}, \mathrm{CaCl}_{2}$ and $\mathrm{NaSO}_{4}$ into distilled water, buffered at $\mathrm{pH} 7.40$ with trishydroxymethyl-aminomethane $\left[\left(\mathrm{CH}_{2} \mathrm{OH}\right)_{3} \mathrm{CNH}_{3}\right]$ and $1 \mathrm{M}$ hydrochloric acid at $36.5^{\circ} \mathrm{C}$. After soaking, the substrates were removed from SBF, washed with distilled water and dried in a clean bench.

\subsection{Analyses of surface and SBF}

Surfaces of polymer substrates before and after the solution treatments were analysed by field-emission scanning electron microscopy (FE-SEM; S-4700, Hitachi Ltd, Japan) attached with energy-dispersive electron X-ray spectroscopy (EDS; EMAX-7000, Horiba Ltd, Japan), thin film X-ray diffraction (TF-XRD; RINT2500, Rigaku Co., Japan), Fourier transform attenuated total reflectance infrared spectroscopy (FT-IR; Magna 860, Nicolet Co., USA) and X-ray photoelectron spectroscopy (XPS; ESCA3200, Shimadzu Co., Japan). In the XPS measurements, $\mathrm{Mg}-\mathrm{K} \alpha(1253.6 \mathrm{eV})$ radiation was used as the $\mathrm{X}$-ray source. The binding energy (BE) scale was calibrated by determining the $\mathrm{BE}$ of $\mathrm{Ag}-3 \mathrm{~d}_{5 / 2}(368.2 \mathrm{eV})$ level, using a spectroscopically pure silver standard, and the energy values were measured with an accuracy of $+0.2 \mathrm{eV}$. For analysis, specimens were attached with carbon tape onto tin holders and placed into an analysis chamber at high vacuum for $24 \mathrm{~h}$ prior to study. The peak shift due to surface charging was corrected using the $\mathrm{C}_{1 \mathrm{~s}}$ level at $285.0 \mathrm{eV}$ as an internal standard. As polymeric substrates might degrade upon exposure to X-rays, all spectra were recorded using low power source and pass energy of $50 \mathrm{eV}$. The recording time for each spectrum was also kept to a minimum to avoid radiation-induced damage (Beamson et al., 1992). All recorded XPS spectra were deconvoluted in several signals that were assumed to have a Gaussian line shape and were resolved into individual components after proper subtraction of baseline, using the Shirley background subtraction method.

In order to study changes of the wettability of the surfaces after alkaline treatments, the static contact angle measurements were obtained by the sessile drop method, using a contact angle meter OCA15+ with high-performance image processing system from DataPhysics Instruments, Germany. The liquids used, glycerol $\left(\mathrm{C}_{3} \mathrm{H}_{8} \mathrm{O}_{3}\right)$ or diiodomethane $\left(\mathrm{CH}_{2} \mathrm{I}_{2}\right)$ (5 and $1.8 \mu \mathrm{l}$, HPLC grade) were added via a motor-driven syringe at room temperature. Six measurements were taken in different regions and averaged on each of five samples for each treatment. The data presented were calculated using the final averaged values. The polarity of the surface and the surface tension were calculated using the Owens-Wendt equation (Owens et al., 1969).

Elemental concentrations and $\mathrm{pH}$ of the SBF before and after soaking of the polymer substrates were measured using inductively coupled plasma atomic emission spectrometry (ICP; SPS-1500VR, Seiko Instruments Inc., Japan).

\section{Results}

\subsection{Surface structural changes of the specimen due to the alkaline treatments}

The modified surfaces were analysed by static contact angle measurements using glycerol (5 $\mu \mathrm{L})$ and diiodomethane $(1.8 \mu \mathrm{L})$ as testing liquids. The total surface energy, as well as the corresponding polar and dispersive components, were calculated by the Owens-Wendt-Kaeble method. The $\mathrm{Ca}(\mathrm{OH})_{2}$ treatment resulted in a smaller glycerol contact angle, while for $\mathrm{NaOH}$-treated samples a larger value was measured. In the case of diiodomethane $\left(\mathrm{CH}_{2} \mathrm{I}_{2}\right)$, an increase was seen after the alkaline treatments (Table 1 ).

The most significant decrease $\left(8.54^{\circ}\right)$ of glycerol contact angle values was measured for $\mathrm{Ca}(\mathrm{OH})_{2}$-treated SEVA-C. Increases in the hydrophilicity of SEVA-C after alkaline treatment can be attributed to an increase in the number of carboxyl groups formed upon hydrolysis, as compared with SEVA-C untreated. The presence of more polar groups was also confirmed by surface tension calculations (Table 1). The polar component increased for both modified materials compared to untreated surfaces, especially in the case of $\mathrm{Ca}(\mathrm{OH})_{2}$ treatment.

Table 2 shows detected elemental lines together with the assignable chemical state of every element in the material surface, on the basis of their binding energies and the corresponding atomic values for SEVA-C. Likewise, Figure 1 shows the $\mathrm{C}_{1 \mathrm{~s}}$ core-level XPS spectra of SEVA-C 
Table 1. Contact angles $(\theta)$ values at room temperature in air and surface energy $\gamma_{s}$, with its dispersive (d) and polar (p) contributions of untreated and modified starch-based polymers

\begin{tabular}{lccccc}
\hline Material & Glycerol $\left(\mathrm{C}_{3} \mathrm{H}_{8} \mathrm{O}_{3}\right) \theta\left(^{\circ}\right)$ & $\mathrm{CH}_{2} \mathrm{I}_{2} \theta\left(^{\circ}\right)$ & $\gamma_{\mathrm{s}}(\mathrm{mN} / \mathrm{m})$ & $\gamma^{\mathrm{d}}(\mathrm{mN} / \mathrm{m})$ & $\gamma_{\mathrm{s}}^{\mathrm{p}}(\mathrm{mN} / \mathrm{m})$ \\
\hline SEVA-C & $78.29 \pm 0.93$ & $51.45 \pm 0.74$ & $33.31 \pm 0.34$ & $32.49 \pm 0.28$ & $0.82 \pm 0.19$ \\
$\mathrm{Ca}(\mathrm{OH})_{2}$-treated SEVA-C & $69.75 \pm 8.75$ & $60.11 \pm 3.82$ & $30.06 \pm 4.22$ & $20.38 \pm 1.35$ & $9.68 \pm 4.00$ \\
$\mathrm{NaOH}$-treated SEVA-C & $90.92 \pm 6.66$ & $77.69 \pm 10.69$ & $21.42 \pm 2.38$ & $19.49 \pm 1.41$ & $1.94 \pm 1.92$ \\
\hline
\end{tabular}

Table 2. XPS spectral data for $\mathrm{C}_{1 \mathrm{~s}}, \mathrm{O}_{1 \mathrm{~s}}, \mathrm{Ca}_{2 \mathrm{p}}$ and $\mathrm{Na}_{1 \mathrm{~s}}$ signals in SEVA-C samples before and after alkaline treatments

\begin{tabular}{|c|c|c|c|c|c|}
\hline \multirow[b]{2}{*}{ Material } & \multicolumn{4}{|c|}{$\mathrm{BE} / \mathrm{eV}$ (relative intensity) } & \multirow[b]{2}{*}{ C:O ratio } \\
\hline & $\mathrm{C}_{1 \mathrm{~s}}$ & $\mathrm{O}_{1 \mathrm{~s}}$ & $\mathrm{Ca}_{2 \mathrm{p}}$ & $\mathrm{Na}_{1 \mathrm{~s}}$ & \\
\hline SEVA-C & $\begin{array}{l}284.86(\mathrm{C}-\mathrm{C}) \\
286.21(\mathrm{C}-0) \\
288.51(\mathrm{C}=0)\end{array}$ & $\begin{array}{l}531.98(\mathrm{O}-\mathrm{C}) \\
532.98(\mathrm{O}=\mathrm{C})\end{array}$ & - & - & 2.85 \\
\hline $\mathrm{Ca}(\mathrm{OH})_{2}$-treated SEVA-C & $\begin{array}{l}285.01(C-C) \\
287.05(C-0) \\
289.81(C=0)\end{array}$ & $\begin{array}{l}531.88(0-\mathrm{C}) \\
532.32(\mathrm{O}=\mathrm{C})\end{array}$ & $347.2(\mathrm{Ca}-0)$ & - & 1.48 \\
\hline $\mathrm{NaOH}$-treated SEVA-C & $\begin{array}{l}285.66(C-C) \\
289.98(C=0)\end{array}$ & $\begin{array}{l}531.98(\mathrm{O}-\mathrm{C}) \\
532.01(\mathrm{O}=\mathrm{C})\end{array}$ & - & $1071.8(\mathrm{Na}-\mathrm{O})$ & 1.91 \\
\hline
\end{tabular}

after alkaline treatments. In Table 2, the increase of the oxygen contents after the alkaline treatments is clear, especially for $\mathrm{Ca}(\mathrm{OH})_{2}$ treatment, which was ascribed to the formation of polar groups.

As can be seen in Figure 1, the $\mathrm{C}_{1 \mathrm{~s}}$ core-level XPS spectrum for SEVA-C has three main peaks, one at $284.86 \mathrm{eV}$, which was assigned to the main backbone carbon peak, and one at about $286.21 \mathrm{eV}$ for the hydroxyl-bonded carbons, due the presence of starch. A broad component with smallest intensity at about $288 \mathrm{eV}$ for carbonyl/carboxyl bonded carbons was also detected. The impurities are the reason for the appearance of the last peak, since none of the components presented in the blend contain carboxyl groups. Poly(ethylenevinyl alcohol) (EVOH) is a commercial material usually derived from the parent vinyl acetate polymers, some traces from which are responsible for this peak appearance (Pemberton et al., 1998).

After the alkaline treatments, a chemical shift to higher energies can be observed in the $\mathrm{C}=\mathrm{O}$ component of XPS $\mathrm{C}_{1 s}$, which is attributed to the significant increase in the concentration of carboxyl groups in the surface of SEVA-C. Also, the reduction of the carbon signal in XPS spectra is even larger in spectra recorded after the alkaline treatments, and the reason for this is the increased of polar groups, viz. $-\mathrm{COOH}$ and $-\mathrm{OH}$, which was confirmed by contact angle and FT-IR measurements.

Moreover, an increase can be seen in the intensities of the bands assigned to $\mathrm{C}-\mathrm{O}$ and $\mathrm{C}=\mathrm{O}$ bonds, compare to those for the main carbon backbone. In the case of $\mathrm{NaOH}$ treatment, the intensity of the band assigned to $\mathrm{C}-\mathrm{O}$ decreases. However, the main component of $\mathrm{C}_{1 \mathrm{~s}}$ signal remains centred at $285.66 \mathrm{eV}$. Also, after immersion in the saturated $\mathrm{Ca}(\mathrm{OH})_{2}$ solution, $\mathrm{Ca}_{2 \mathrm{p}}$ core-level signal centred at $347.2 \mathrm{eV}$ are observed

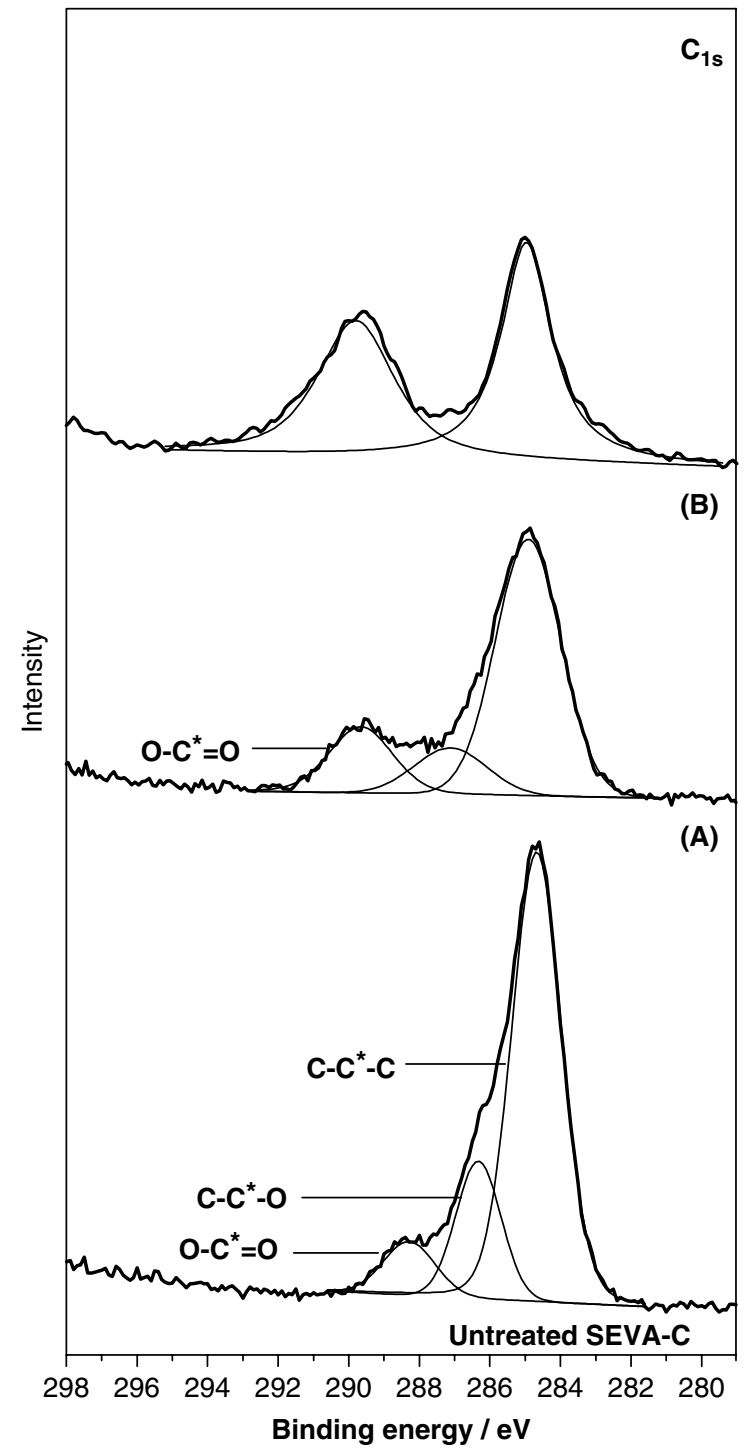

Figure 1. $\mathrm{C}_{1 \mathrm{~s}}$ XPS spectra of the surface of SEVA-C after being subjected to $\mathrm{Ca}(\mathrm{OH})_{2}$ (A) and $\mathrm{NaOH}(\mathrm{B})$ treatments 
in spectra for SEVA-C. For NaOH-treated SEVA-C spectra, the $\mathrm{Na}_{\mathrm{s}}$ core-level line is detected centred at $1071.8 \mathrm{eV}$, which is assigned to $\mathrm{Na}-\mathrm{O}$ bonds (Beamson et al., 1992). These data are displayed in Table 2.

Figure 2 show FT-IR spectra of the surfaces of SEVA-C polymer, which were subjected to different treatments. When SEVA-C was treated with $\mathrm{Ca}(\mathrm{OH})_{2}$ and $\mathrm{NaOH}$, remarkable changes were observed in the FT-IR. In the spectra, and for both treatments, it was possible to observe reflection bands around $1750,1450,1410$ and $860 \mathrm{~cm}^{-1}$ that were attributed to the presence of $-\mathrm{COOH}$ (see Figure 2) (Socrates et al., 1998). However, a decrease in the intensity of bands assigned to $-\mathrm{OH}$ stretching vibration of starch and vinyl alcohol hydroxyl groups (in the region of $3500-3100 \mathrm{~cm}^{-1}$ ) was observed after alkaline treatments, probably due to the oxidation of those groups to carboxyl ones.

\subsection{Surface structural changes of specimens in SBF}

Figure 3 shows TF-XRD patterns of the surfaces of SEVA$\mathrm{C}$ polymer, which were subjected to the treatments, and those subjected to soaking in SBF for up to 7 days. For SEVA-C untreated surface, no changes were observed after soaking in SBF for 7 days, as shown in the TFXRD patterns (see Figure 3 ). In the case of $\mathrm{Ca}(\mathrm{OH})_{2}$ and $\mathrm{NaOH}$-treated SEVA-C, the results were completely different from the SEVA-C untreated, as can be observed in the TF-XRD (see Figure 3).

For both alkaline treatments, it can be observed that the structure of SEVA-C remains unaltered after $\mathrm{Ca}(\mathrm{OH})_{2}$ and $\mathrm{NaOH}$ treatment, showing the same reflections

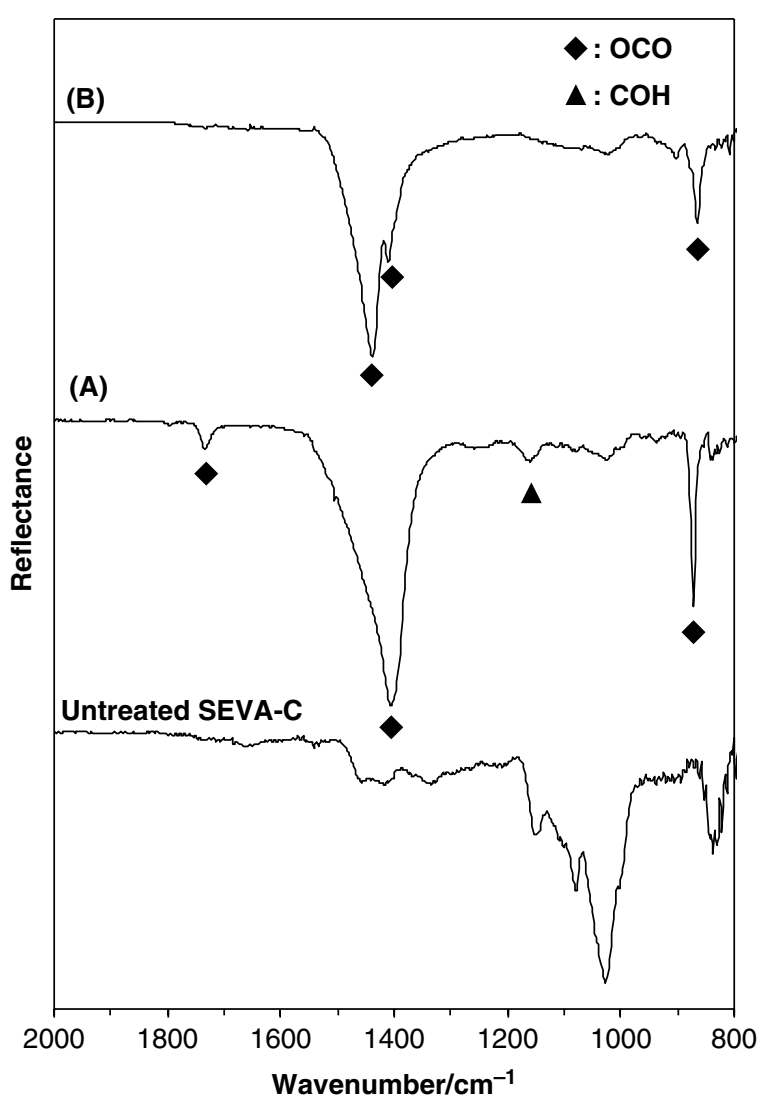

Figure 2. FT-IR spectra of the surfaces of SEVA-C, which were subjected to $\mathrm{Ca}(\mathrm{OH})_{2}(\mathrm{~A})$ and the $\mathrm{NaOH}(\mathrm{B})$ treatments

observed for untreated specimen (see Figure 3). On the other hand, SEVA-C substrates undergo several surface changes after $\mathrm{Ca}(\mathrm{OH})_{2}$ treatment which involve the nucleation of poorly-crystalline calcium hydroxide $\left(\mathrm{Ca}(\mathrm{OH})_{2}\right.$; ASTM JCPDS 50-0008), as can be observed
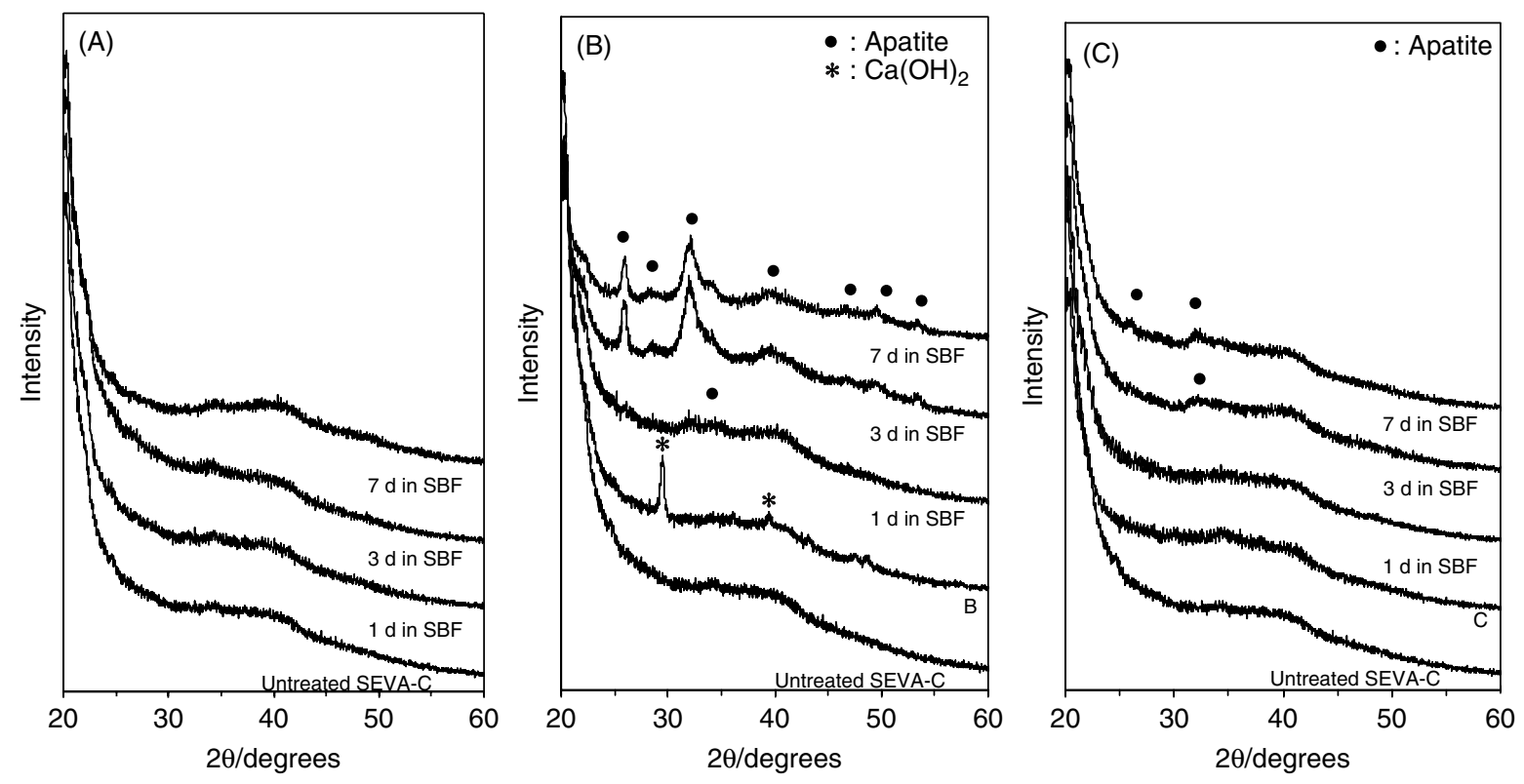

Figure 3. TF-XRD patterns of the surfaces of SEVA-C (A), which were subjected to $\mathrm{Ca}(\mathrm{OH})_{2}(\mathrm{~B})$ and $\mathrm{NaOH}(\mathrm{C})$ treatments and to soaking in SBF for 1, 3 and 7 days 
in Figure 3. Moreover, TF-XRD patterns of the surface of polymer substrates after soaking in SBF for several periods (using non-immersed samples as controls) show several diffraction maxima that can be assigned to an apatitelike phase (ASTM JCPDS 9-432). However, apatite peaks were observed within 1 day for $\mathrm{Ca}(\mathrm{OH})_{2}$-treated SEVA$\mathrm{C}$ and 3 days for $\mathrm{NaOH}$-treated SEVA-C after soaking in SBF (see Figure 3). As the soaking time increases, the intensities of the apatite peaks increase and become more intense.
By FE-SEM analysis, once more, one could see that SEVA-C can not induce the formation of an apatite layer by itself, as shown in Figure 4. Also, by EDS analysis no signal was detected of calcium (Ca) or phosphorus (P) on the surface of SEVA-C.

Figures 5-7 show the FE-SEM images and EDS spectra of the SEVA-C substrates before and after $\mathrm{Ca}(\mathrm{OH})_{2}$ and $\mathrm{NaOH}$ treatment and subsequent soaking in SBF for up to 7 days. It can be seen from Figure 5 that a dense and uniform apatite layer could be formed on SEVA-C substrate.
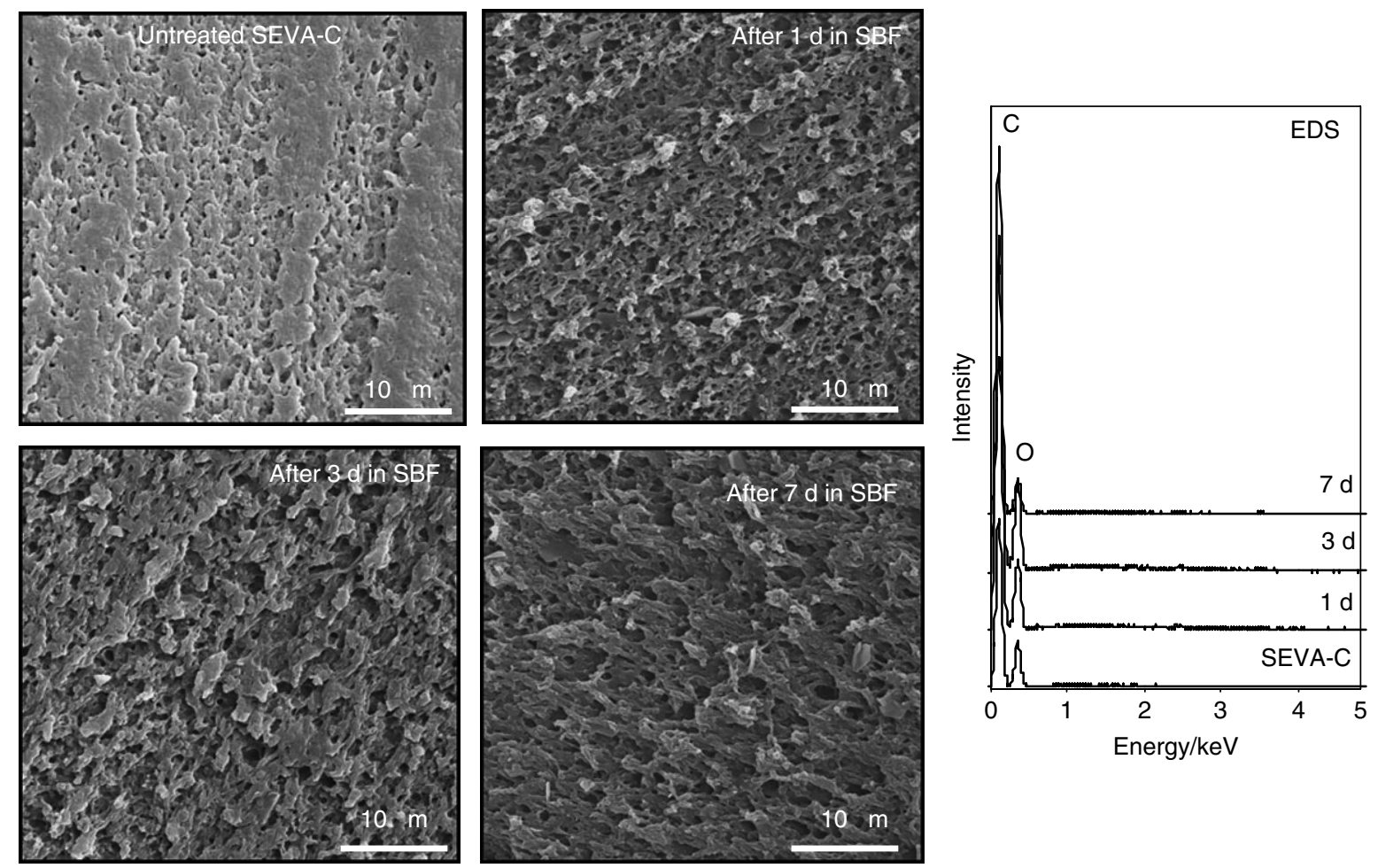

Figure 4. SEM-EDS profiles of the surface of SEVA-C after soaking in SBF for several periods of time
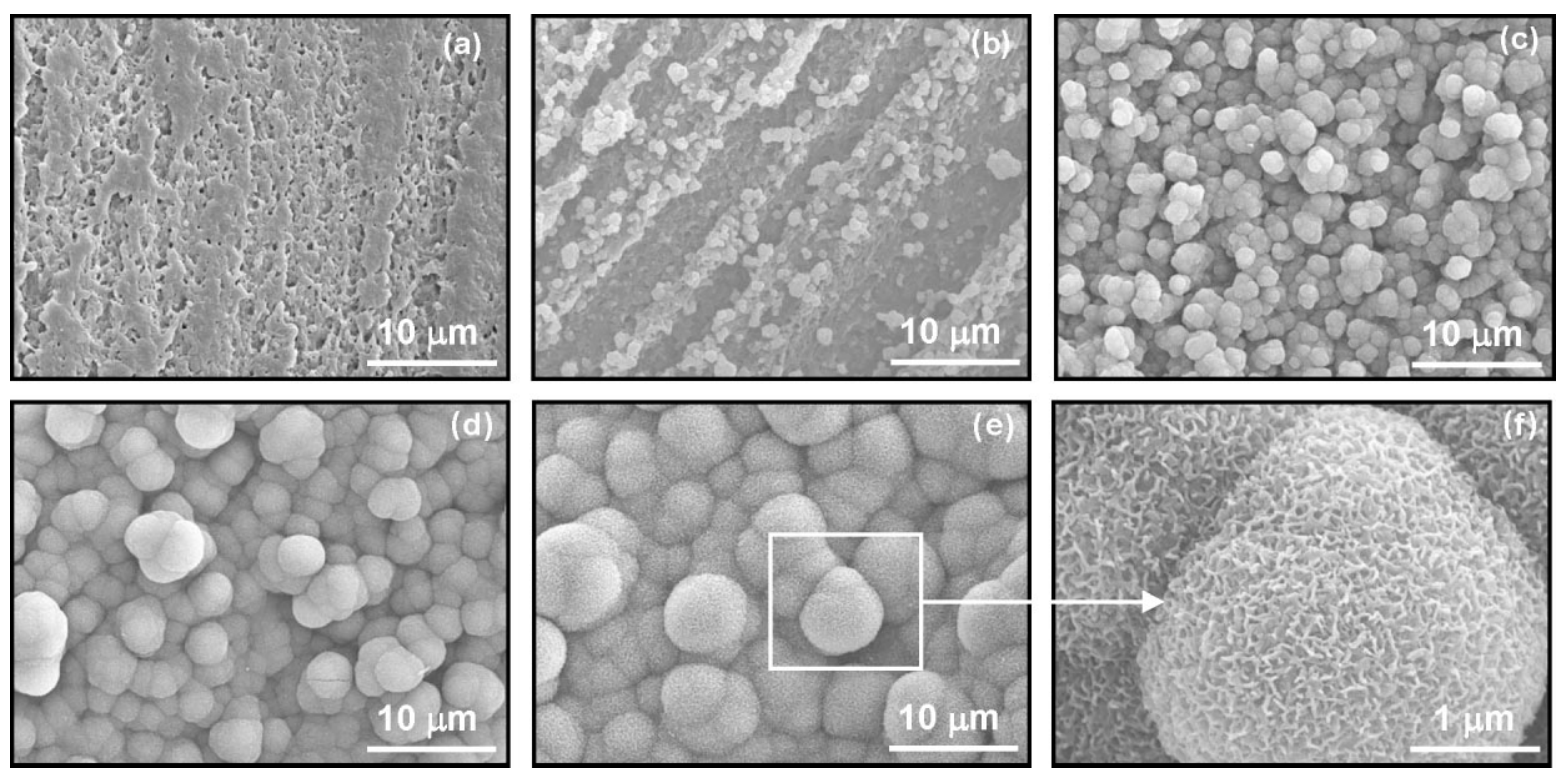

Figure 5. SEM photographs of the surfaces of SEVA-C (a), which were subjected to $\mathrm{Ca}(\mathrm{OH})_{2}$ treatment (b) and to soaking in SBF for 1 (c), 3 (d) and 7 (e) days. Magnification (f) showing a detail of the structure presented in (e) 

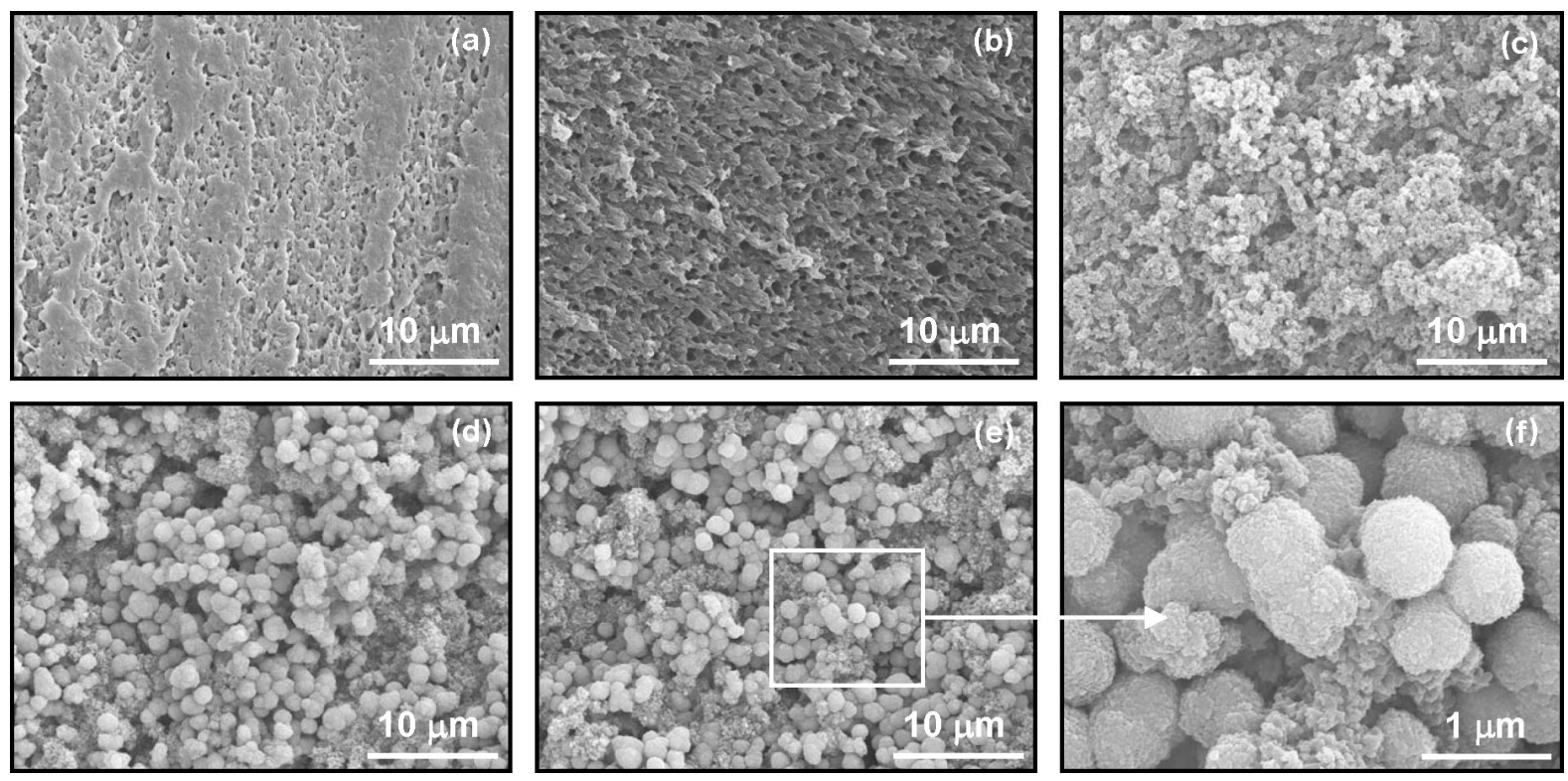

Figure 6. SEM photographs of the surfaces of SEVA-C (a), which were subjected to the NaOH treatment (b) and to soaking in SBF for 1 (c), 3 (d) and 7 (e) days. Magnification (f) showing a detail of the structure presented in (e)

For $\mathrm{Ca}(\mathrm{OH})_{2}$-treated SEVA-C, an apatite layer was observed after only 1 day of immersion in SBF (Figure 5c). As the soaking time increases, it can be seen that the apatite nuclei grew in size by consuming calcium and phosphorus ions from the SBF solution. Also, the film became more compact and dense. Moreover, at higher magnifications there is evidence of a finer structure, where needle-like crystals are agglomerated (Figure 5f).

In the case of NaOH-treated SEVA-C, only after 3 days was the formation of apatite nuclei observed (Figure 6d). After 1 day in SBF it was only possible to observe the precipitation of calcium phosphate.

The EDS spectra of $\mathrm{Ca}(\mathrm{OH})_{2}$-treated SEVA-C show a signal of Ca (Figure 7a) that is in good agreement with the detection of $\mathrm{Ca}(\mathrm{OH})_{2}$ in TF-XRD patterns (Figure 3). After this treatment, particles can be observed spreading over the entire SEVA-C surface (Figure 5b).

After soaking in SBF, a strong signal ascribed to $\mathrm{P}$ and $\mathrm{Ca}$ was detected. As the soaking time in SBF increased, the intensity of $\mathrm{Ca}$ and $\mathrm{P}$ signals significantly increased. In addition, the presence was detected of $\mathrm{Na}$ and $\mathrm{Mg}$ signals, which precipitated from the SBF solution.

For NaOH-treated SEVA-C, the EDS spectra showed a signal of $\mathrm{Na}$ (Figure $\mathrm{7b}$ ). However, there was no formation of any particles on the SEVA-C surface (Figure 6b). After soaking in SBF for 1 day, a small signal ascribed to $P$ and $\mathrm{Ca}$ was detected. As the soaking time in SBF increased, the intensity of $\mathrm{Ca}$ and $\mathrm{P}$ signals increased significantly. However, the intensity of these signals was lower than those observed on the surface of $\mathrm{Ca}(\mathrm{OH})_{2}$-treated SEVA-C.

Figure 8 shows the concentrations of $\mathrm{Ca}$ and $\mathrm{P}$ in the $\mathrm{SBF}$ as a function of immersion time of $\mathrm{Ca}(\mathrm{OH})_{2}$-treated SEVA-C and $\mathrm{NaOH}$-treated SEVA-C. For $\mathrm{Ca}(\mathrm{OH})_{2}$-treated polymer, a slight increase in Ca concentration in the SBF could be observed during the first $24 \mathrm{~h}$ of soaking, which was due to the release of $\mathrm{Ca}^{2+}$ ions from the surface to SBF. In the case of $\mathrm{NaOH}$-treated polymer, after 1 day of soaking, a steep decrease in the Ca and $P$ concentrations in the SBF could be noticed, pointing to a quick consumption of such species from SBF. As the immersion time increased, $\mathrm{Ca}$ and $\mathrm{P}$ concentrations decreased gradually, probably due to the formation of apatite by consuming the calcium and phosphate ions in the fluid.

For untreated SEVA-C, no change was observed in the $\mathrm{Ca}$ and $\mathrm{P}$ concentrations; as mentioned above, SEVA$C$ shows non-bioactive behaviour when soaked in SBF solution.

\section{Discussion}

The biodegradable thermoplastic blend of corn starch with ethylene-vinyl alcohol (SEVA-C) has one important functional group, the hydroxyl group $(-\mathrm{OH})$. EVOH is constituted of segments of hydrophobic ethylene and a hydrophilic vinyl alcohol with reactive hydroxyl groups. The starch is a polysaccharide, which is constituted primarily by two types of molecules: one known as amylose, a mostly linear $\alpha$-D-(1-4)-glucan, and the other as amylopectin, an $\alpha$-D-(1-4) glucan, which has $\alpha$-D(1-6) linkages at the branch point (Galliard et al., 1987; Reis et al., 2001). As can be seen from Figure 9, starch contains an abundance of - $\mathrm{OH}$ groups. Each anhydroglucose unit contains two secondary $-\mathrm{OH}$ groups and a large majority containing primary $-\mathrm{OH}$ groups. The $-\mathrm{OH}$ groups are susceptible to substitution reactions (Chandra et al., 1998). However, the presence of a large number of these groups on SEVA-C substrate was not sufficient to induce apatite formation, as shown in this work. These results are in agreement with the results of Tanahashi et al. (1997), which indicate that these groups have 

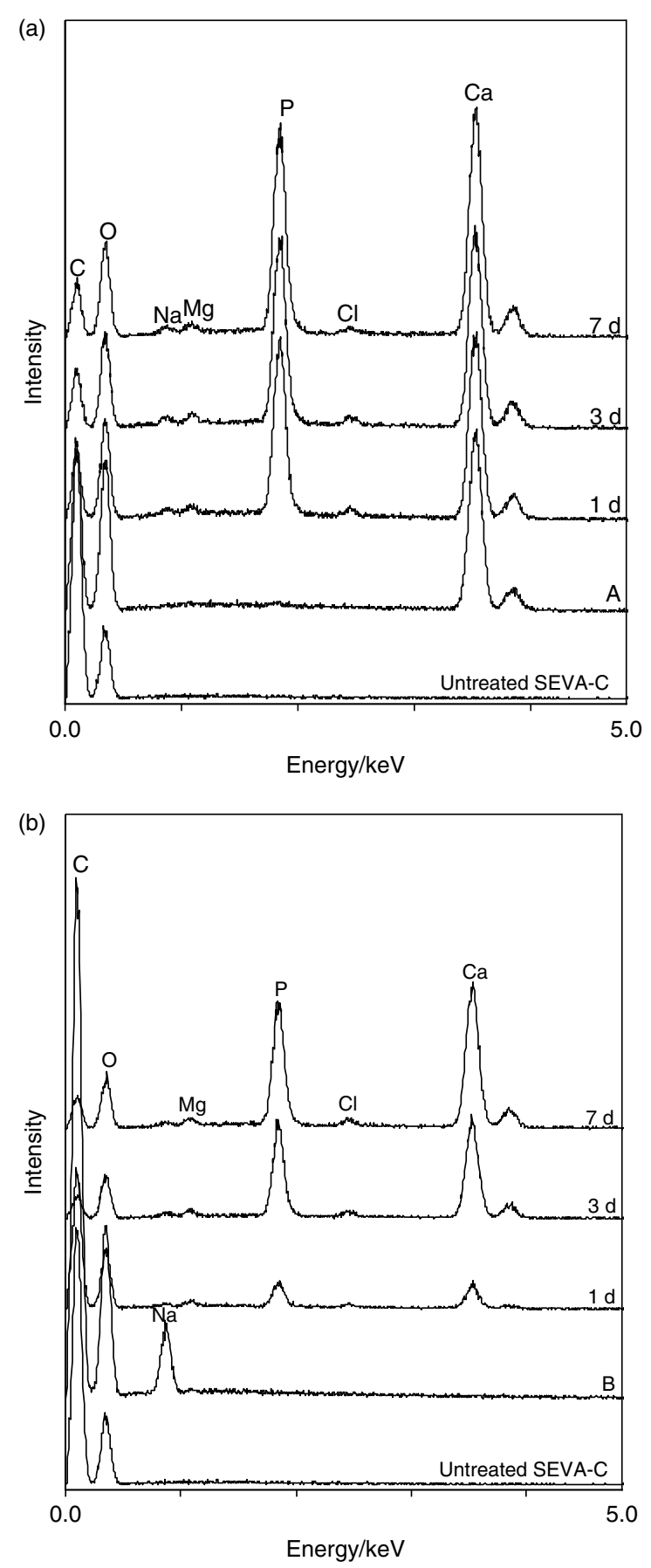

Figure 7. EDS spectra of the surfaces of SEVA-C, which were subjected to (a) $\mathrm{Ca}(\mathrm{OH})_{2}$ (A, left) and (b) $\mathrm{NaOH}$ (B, right) treatments and subsequent soaking in SBF for several periods of time

weaker apatite nucleating ability, i.e. they require a period longer than 7 days of soaking in SBF.

It has been reported previously (Leonor et al., 2002a, 2002b, 2003, 2004; Leonor et al., 2003; Oliveira et al., 1999, 2003, 2004, 2005; Pashkuleva et al., 2005) that SEVA-C cannot induce the formation of an apatite layer on its surface if not modified. Moreover, as can be observed after FT-IR and TF-XRD measurements, untreated SEVAC, i.e. without alkaline treatment, is not able to form apatite on its surface in SBF even after 7 days. On the other hand, when SEVA-C is soaked in the two alkaline solutions it has the capacity to induce the formation of an apatite layer after soaking in SBF for several periods of time, as shown in FE-SEM images (Figures 5, 6).

The surface functionalization of SEVA-C can be achieved via chemical etching/hydrolysis. By chemical etching a very thin layer from the SEVA-C surface was removed in such a way as to expose the polar groups present in the structure of starch, since hydrolysis of polar polymers (such as that of SEVA-C) leads to the formation of a surface rich in carboxyl groups. Hydroxyl ions in alkaline solution react with starch, resulting in chain scission and leaving hydrophilic carboxyl and hydroxyl groups on the SEVA-C surface. Polymers, starch and $\mathrm{EVOH}$ are subjected to hydrolysis. So, the hydrolysis was catalysed under alkaline conditions, in which part of starch was hydrolysed, and generated $-\mathrm{COOH}$ as well as - $\mathrm{OH}$ groups, as it can be seen from FT-IR and XPS data. These results are in agreement with the results from contact angle measurements, where more polar groups have been introduced on the surface.

The $-\mathrm{COOH}$ groups in a solution at $\mathrm{pH} \quad 7.4$ became negatively charged. These groups, enhanced by alkaline hydrolysis, regulated calcium binding from the SBF solution and as a result increased the ionic activity product, which accelerated the apatite nucleation rate. Once apatite nuclei are formed, they can grow spontaneously into a uniform layer by consuming the calcium and phosphate ions from the SBF (Kim et al., 2001). This is supported by ICP measurements shown in Figure 8.

However, there are some significant differences between the two alkaline treatments. When SEVA-C was soaked in $\mathrm{Ca}(\mathrm{OH})_{2}$ saturated solution and then in SBF, formation of a uniform apatite layer could be observed only after 1 day. This was due to the formation of $-\mathrm{COOH}$ groups, and at the same time, after being treated with saturated $\mathrm{Ca}(\mathrm{OH})_{2}$ solution, a large number of the calcium ions combined with the - $\mathrm{COOH}$ groups of SEVA-C. In addition, the water uptake capability of this polymer allowed the material to absorb higher quantities of $\mathrm{Ca}^{2+}$ ions from the calcium solution. Then, during the subsequent soaking in SBF, some of the calcium ions were released into the SBF, leading to an increase of calcium concentration (see Figure 8). These $\mathrm{Ca}^{2+}$ ions were able to form - $\mathrm{COOH}$ groups effective in apatite nucleation on the surface of SEVA-C and simultaneously accelerate the apatite nucleation by increasing the ionic activity product of the apatite in the SBF. Once apatite nuclei were formed, they could spontaneously grow into a uniform layer by consuming the calcium and phosphate ions from the SBF (Kim et al., 2001).

In contrast, the $\mathrm{NaOH}$-treated SEVA-C formed apatite nuclei with calcium phosphate precipitation only after 3 days in SBF. Reasons for this result include the high concentration of the $\mathrm{NaOH}$ solution and the water uptake properties of SEVA-C, which allow the material to absorb high quantities of sodium $\left(\mathrm{Na}^{+}\right)$ions. As result, the $-\mathrm{COOH}$ groups were bonded to $\mathrm{Na}^{+}$ions and, when 

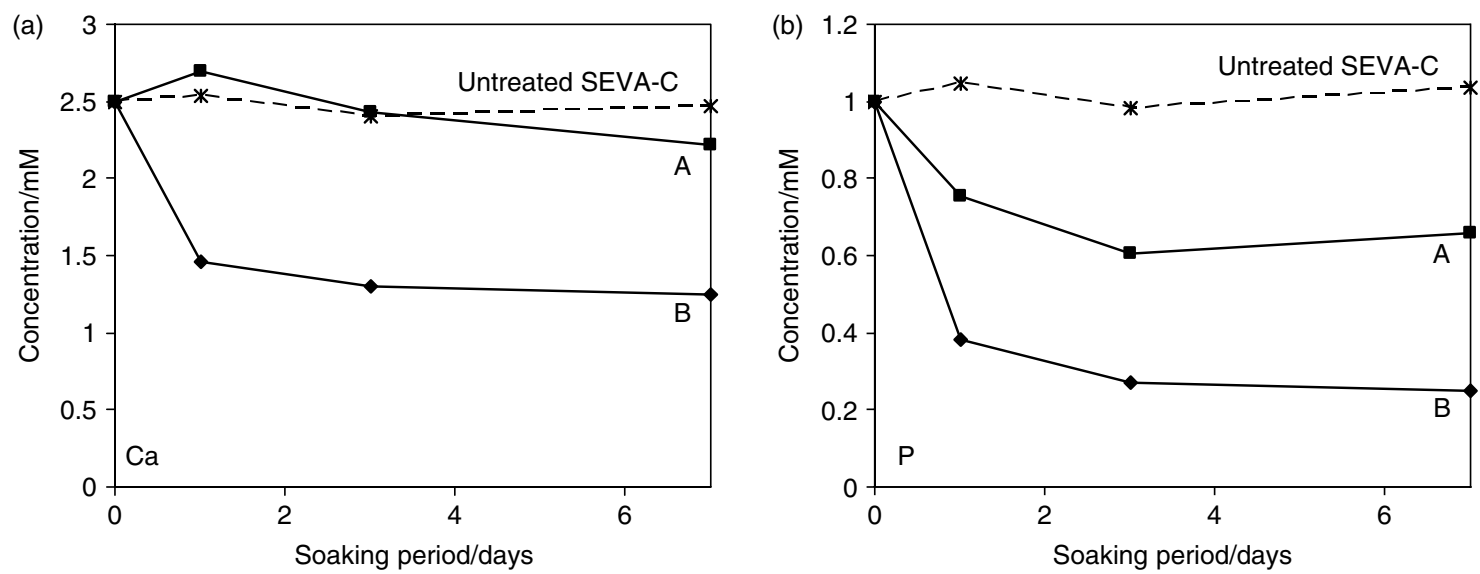

Figure 8. Changes in (a) $\mathrm{Ca}$ and (b) $\mathrm{P}$ concentration of the SBF with soaking time of the SEVA-C which were subjected to $\mathrm{Ca}(\mathrm{OH})_{2}$ (A) and $\mathrm{NaOH}(B)$ treatment

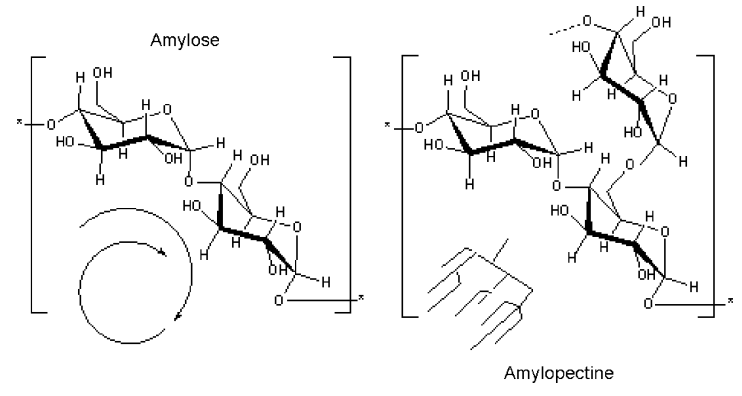

Figure 9. Structure of amylose and amylopectin

soaked in SBF, the $\mathrm{Ca}^{2+}$ ions present in the solution had nowhere to bond, since the $-\mathrm{COOH}$ groups were bonded with $\mathrm{Na}^{+}$ions. These results are in agreement with those obtained from contact angles and XPS, where the intensity of the $\mathrm{Na}_{1 \text { s }}$ core-level signal was very high. Then, for the formation of the apatite more time is needed for $\mathrm{Ca}^{2+}$ ions replace the $\mathrm{Na}^{+}$ions and to bind the $-\mathrm{COOH}$ present in the structure of SEVA-C, compared to $\mathrm{Ca}(\mathrm{OH})_{2}$ treatment. Also, when the specimen was soaked in SBF, the $\mathrm{Na}^{+}$ions in the surface layer were released into $\mathrm{SBF}$, which has great capacity to bind with the carbonate $\left(\mathrm{CO}_{3}{ }^{-}\right)$ion from SBF solution, and led to the formation of sodium carbonate $\left(\mathrm{Na}_{2} \mathrm{CO}_{3}\right)$. Consequently, the amount of calcium phosphate deposited on the $\mathrm{NaOH}$-treated SEVA-C was less, i.e. the formation of the apatite layer was delayed due to the - $\mathrm{COOH}$ groups being occupied by $\mathrm{Na}^{+}$and not being available for bonding with $\mathrm{Ca}^{2+}$ ions to induce the apatite nucleation.

The surface apatite layer formed on the $\mathrm{Ca}(\mathrm{OH})_{2}$ treated SEVA-C adhered to the specimen surface so strongly that the apatite layer was not peeled off from the surface of the specimen, even by a simple preliminary tape-detaching test, using Scotch $^{\circledR}$ tape. In addition, EDS spectra recorded before and after the detaching test showed that the apatite layer was highly attached to surface. This strong adhesion might be caused by the ionic interaction between the $-\mathrm{OH}$ and $-\mathrm{COOH}$ groups on the specimen surface and the apatite crystals.
According to the results discussed above, submission of SEVA-C specimens to alkaline treatments provided a polymer surface with precursors of apatite, prior to soaking in SBF, which significantly reduced the period required for apatite deposition from SBF. The induction period required for the apatite nucleation is dependent on the kind (Tanahashi et al., 1997), number (Oyane et al., 1999) and arrangement (Oyane et al., 2002) of the functional groups. Therefore, the period required for inducing apatite nucleation is a crucial factor in the apatite-forming ability of the any material in SBF. This simple functionalization via etching and hydrolysis provides a polymeric surface with precursors of apatite, prior to the soaking in SBF, and this causes shortening of period required for the apatite deposition from SBF. Moreover, due to its great simplicity, the present surface modification has advantages in terms of cost and processing time.

\section{Conclusions}

A thin layer of bone-like apatite could be formed on a starch-based biodegradable polymer within 1 and 7 days, when SEVA-C was previously treated with aqueous $\mathrm{Ca}(\mathrm{OH})_{2}$ and $\mathrm{NaOH}$, respectively. Such alkaline treatments increase the amount of surface hydroxyls and carboxylic acid groups, which regulates calcium binding and heterogeneous apatite growth on SEVA-C specimens. These results suggest that this rather simple treatment is a good method for surface functionalization and subsequent inducement of mineral nucleation and growth on biodegradable polymers to be used for bone-related applications.

\section{Acknowledgements}

I. B. Leonor thanks the Portuguese Foundation for Science and Technology for providing a $\mathrm{PhD}$ scholarship (SFRH/BD/9031/2002). This work was partially supported by 
the Foundation for Science and Technology (FCT) through funds from the POCTI and/or FEDER programmes.

\section{References}

Azevedo HS, Gama FM, Reis RL. 2003; In vitro assessment of the enzymatic degradation of several starch based biomaterials. Biomacromolecules 4: 1703-1712.

Beamson G, Briggs D. 1992; High Resolution XPS of Organic Polymers: The Scientia ESCA300 Database. Wiley: Chichester.

Boesel LF, Fernandes MH, Reis RL. 2004a; The behavior of novel hydrophilic composite bone cements in simulated body fluids. $J$ Biomed Mater Res 70B: 368-377.

Boesel LF, Mano JF, Reis RL. 2004b; Optimization of the formulation and mechanical properties of starch based partially degradable bone cements. J Mater Sci Mater Med 15: 73-83.

Bostman O, Pihlajamaki H. 2000; Clinical biocompatibility of biodegradable orthopaedic implants for internal fixation: a review. Biomaterials 21: 2615-2621.

Campbell AA. 1999; Interfacial regulation of crystallization in aqueous environments. Curr Opin Colloid Interface Sci 4: 40-45.

Chandra R, Rustgi R. 1998; Biodegradable polymers. Progr Polymer Sci 23: 1273-1335.

Demirgoz D, Elvira C, Mano JF, et al. 2000; Chemical modification of starch based biodegradable polymeric blends: effects on water uptake, degradation behaviour and mechanical properties. Polym Degrad Stabil 70: 161-170.

Elvira C, Mano JF, San Roman J, et al. 2002; Starch-based biodegradable hydrogels with potential biomedical applications as drug delivery systems. Biomaterials 23: 1955-1966.

Galliard T. 1987; Starch: properties and potential. Crit Rep Appl Chem 13: 1-15.

Gomes ME, Godinho JS, Tchalamov D, et al. 2002; Alternative tissue engineering scaffolds based on starch: processing methodologies, morphology, degradation and mechanical properties. Mat Sci Eng C-Bio S 20: 19-26.

Gomes ME, Holtorf HL, Reis RL, et al. 2006; Influence of the porosity of starch-based fiber mesh scaffolds on the proliferation and osteogenic differentiation of bone marrow stromal cells cultured in a flow perfusion bioreactor. Tissue Eng 12: 801-809.

Gomes ME, Reis RL, Cunha AM, et al. 2001; Cytocompatibility and response of osteoblastic-like cells to starch-based polymers: effect of several additives and processing conditions. Biomaterials 22: 1911-1917.

Gomes ME, Sikavitsas VI, Behravesh E, et al. 2003; Effect of flow perfusion on the osteogenic differentiation of bone marrow stromal cells cultured on starch-based three-dimensional scaffolds. $J$ Biomed Mater Res 67A: 87-95.

Hastings GW. 1994; Is there an ideal biomaterial for use as an implant for fracture fixation? In Biodegradable Implants in Fracture Fixation, Kwok-Sui L, Leung-Kim H, Ping-Chung L (eds). World Scientific: Hong Kong; 19-33.

Hayashi T. 1994; Biodegradable Polymers for Biomedical Uses. Progr Polym Sci 19: 663-702.

Kim H-M. 2001; Bioactive ceramics: challenges and perspectives. $J$ Ceram Soc Japan 109: S49-57.

Kim HM. 2003; Ceramic bioactivity and related biomimetic strategy. Curr Opin Solid State Mater Sci 7: 289-299.

Kokubo T, Kim HM, Kawashita M. 2003; Novel bioactive materials with different mechanical properties. Biomaterials 24: 2161-2175.

Kokubo T, Kim HM, Kawashita M, et al. 2004; Bioactive metals: preparation and properties. J Mater Sci Mater Med 15: 99-107.

Kokubo T, Kushitani H, Sakka S, et al. 1990; Solutions able to reproduce in vivo surface-structure changes in bioactive glass-ceramic A-W. J Biomed Mater Res 24: 721-734.

Kokubo T, Takadama H. 2006; How useful is SBF in predicting in vivo bone bioactivity? Biomaterials 27: 2907-2915.

Leonor IB, Ito A, Onuma K, et al. 2003; In vitro bioactivity of starch thermoplastic/hydroxyapatite composite biomaterials: an in situ study using atomic force microscopy. Biomaterials 24: 579-585.

Leonor IB, Ito A, Onuma K, et al. 2002a; In situ study of partially crystallized Bioglass and hydroxyapatite in vitro bioactivity using atomic force microscopy. J Biomed Mater Res 62: 82-88.

Leonor IB, Kim H-M, Balas F, et al. 2005; Functionalization of different polymers with sulfonic groups as a way to coat them with a biomimetic apatite layer. J Mater Sci Mater Med 2007; 18(10): 1923-1930.

Leonor IB, Kim H-M, Balas F, et al. 2007; Surface potential change of polyethylene modified with sulfonic functional groups in simulated body fluid. $J$ Mater Chem 2007; 17: 4057-4063.

Leonor IB, Reis RL. 2003; An innovative auto-catalytic deposition route to produce calcium phosphate coatings on polymeric biomaterials. J Mater Sci Mater Med 14: 435-441.

Leonor IB, Sousa RA, Cunha AM, et al. 2002b; Novel starch thermoplastic/Bioglass composites: mechanical properties, degradation behavior and in vitro bioactivity. $J$ Mater Sci Mater Med 13: 939-945.

Leonor IL, Azevedo HS, Pashkuleva I, et al. 2004; Learning from nature how to design biomimetic calcium-phosphate coatings. In Learning from Nature How to Design New Implantable Biomaterials : From Biomineralization Fundamentals to Biomimetic Materials and Processing Routes, Reis RL, Weiner S (eds). Kluwer Academic: Dordrecht; 123-150.

Malafaya PB, Stappers F, Reis RL. 2006; Starch-based microspheres produced by emulsion crosslinking with a potential media dependent responsive behavior to be used as drug delivery carriers. J Mater Sci Mater Med 17: 371-377.

Mano JF, Koniarova D, Reis RL. 2003; Thermal properties of thermoplastic starch/synthetic polymer blends with potential biomedical applicability. J Mater Sci Mater Med 14: 127-135.

Mano JF, Reis RL, Cunha AM. 2000; Effects of moisture and degradation time over the mechanical dynamical performance of starch-based biomaterials. J Appl Polym Sci 78: 2345-2357.

Mano JF, Sousa RA, Boesel LF, et al. 2004; Bioinert, biodegradable and injectable polymeric matrix composites for hard tissue replacement: state of the art and recent developments. Composit Sci Technol 64: 789.

Marques AP, Reis RL, Hunt JA. 2002; The biocompatibility of novel starch-based polymers and composites: in vitro studies. Biomaterials 23: 1471-1478.

Marques AP, Reis RL, Hunt JA. 2003; Evaluation of the potential of starch-based biodegradable polymers in the activation of human inflammatory cells. J Mater Sci Mater Med 14: 167-173.

Marques AP, Reis RL, Hunt JA. 2005a; An in vivo study of the host response to starch-based polymers and composites subcutaneously implanted in rats. Macromol Biosci 5: 775-785.

Marques AP, Reis RL, Hunt JA. 2005b; The effect of starch-based biomaterials on leukocyte adhesion and activation in vitro. J Mater Sci Mater Med 16: 1029-1043.

Mendes SC, Bezemer J, Claase MB, et al. 2003; Evaluation of two biodegradable polymeric systems as substrates for bone tissue engineering. Tissue Eng 9: S91-101.

Mendes SC, Reis RL, Bovell YP, et al. 2001; Biocompatibility testing of novel starch-based materials with potential application in orthopaedic surgery: a preliminary study. Biomaterials 22: 2057-2064.

Middleton JC, Tipton AJ. 2000; Synthetic biodegradable polymers as orthopedic devices. Biomaterials 21: 2335-2346.

Oliveira AL, Elvira C, Reis RL, et al. 1999; Surface modification tailors the characteristics of biomimetic coatings nucleated on starch-based polymers. J Mater Sci Mater Med 10: 827-835.

Oliveira AL, Malafaya PB, Reis RL. 2003; Sodium silicate gel as a precursor for the in vitro nucleation and growth of a bonelike apatite coating in compact and porous polymeric structures. Biomaterials 24: 2575-2584.

Oliveira AL, Mano JF, Roman JS, et al. 2005; Study of the influence of $\beta$-radiation on the properties and mineralization of different starch-based biomaterials. J Biomed Mater Res B Appl Biomater 74: 560-569.

Oliveira AL, Reis RL. 2004; Pre-mineralisation of starch/polycrapolactone bone tissue engineering scaffolds by a calcium silicatebased process. J Mater Sci Mater Med 15: 533-540.

Owens DK, Wendt RC. 1969; Estimation of surface free energy of polymers. J Appl Polym Sci 13: 1741-1747.

Oyane A, Kawashita M, Kokubo T, et al. 2002; Bonelike apatite formation on ethylene-vinyl alcohol co-polymer modified with a silane coupling agent and titania solution. J Ceram Soc Japan 110: $248-254$.

Oyane A, Minoda M, Miyamoto T, et al. 1999; Apatite formation on ethylene-vinyl alcohol co-polymer modified with silanol groups. J Biomed Mater Res 47: 367-373.

Pashkuleva I, Marques AP, Vaz F, et al. 2005; Surface modification of starch based blends using potassium permanganate-nitric 
acid system and its effect on the adhesion and proliferation of osteoblast-like cells. J Mater Sci Mater Med 16: 81-92.

Pemberton L, De Jaeger R, Gengembre L. 1998; Grafting of a thin layer of poly(organophosphazene) containing succinic anhydride groups onto poly(vinyl alcohol) and poly(ethylene-co-vinyl alcohol). Polymer 39: 1299-1307.

Reis RL, Cunha AM. 1995; Characterization of two biodegradable polymers of potential application within the biomaterials field. $J$ Mater Sci Mater Med 6: 786-792.

Reis RL, Cunha AM. 2000; New degradable load-bearing biomaterials based on reinforced thermoplastic starch incorporating blends. $J$ Appl Med Polym 4: 1-5.

Reis RL, Cunha AM. 2001; Starch and starch-based thermoplastics. In Encyclopedia of Materials: Science and Technology, Buschow KHJ, et al. (eds). Elsevier Science: The Netherlands; 8810-8816.

Reis RL, Cunha AM, Allan PS, et al. 1996; Mechanical behavior of injection-molded starch-based polymers. Polym Adv Technol 7: 784-790.

Reis RL, Mendes SC, Cunha AM, et al. 1997; Processing and in vitro degradation of starch/EVOH thermoplastic blends. Polym Int 43: 347-352.

Rokkanen PU. 1991; Absorbable materials in orthopaedic surgery. Ann Med 23: 109-115.

Salgado AJ, Coutinho OP, Reis RL. 2004; Novel starch-based scaffolds for bone tissue engineering: cytotoxicity, cell culture, and protein expression. Tissue Eng 10: 465-474.
Salgado AJ, Figueiredo JE, Coutinho OP, et al. 2005; Biological response to pre-mineralized starch-based scaffolds for bone tissue engineering. J Mater Sci Mater Med 16: 267-275.

Socrates G. 1998; Infrared Characteristic Group Frequencies. Wiley: Chichester.

Sousa RA, Kalay G, Reis RL, et al. 2000; Injection molding of a starch/EVOH blend aimed as an alternative biomaterial for temporary applications. J Appl Polym Sci 77: 1303-1315.

Sousa RA, Mano JF, Reis RL, et al. 2002; Mechanical performance of starch based bioactive composite biomaterials molded with preferred orientation. Polym Eng Sci 42: 1032-1045.

Suh H. 1998; Recent advances in biomaterials. Yonsei Med J 39: 87-96.

Tanahashi M, Matsuda T. 1997; Surface functional group dependence on apatite formation on self-assembled monolayers in a simulated body fluid. J Biomed Mater Res 34: 305-315.

Temenoff JS, Mikos AG. 2000; Injectable biodegradable materials for orthopedic tissue engineering. Biomaterials 21: 2405-2412.

Vainionpää S, Rokkanen P, Törmälä P. 1989; Surgical applications of biodegradable polymers in human tissues. Progr Polym Sci 14: 679-716.

Vaz CM, Reis RL, Cunha AM. 2001; Degradation model of starch-EVOH plus HA composites. Mater Res Innov 4: 375-380.

Weiner S. 1986; Organization of extracellularly mineralized tissues: a comparative study of biological crystal growth. CRC Crit Rev Biochem 20: 365-408. 